\title{
Can the Recall Improve Electoral Representation?
}

\author{
Pierre-Etienne Vandamme* \\ Cevipol, FNRS \& Université libre de Bruxelles, Brussels, Belgium
}

Empirical studies reveal many citizens' unwillingness to get rid of representative democracy. A great number of them, however, distrust their representatives and would want representation to be improved, for example by giving citizens more control over their representatives. One possible mechanism of control is the recall-the possibility to remove elected representatives from office through a vote before the end of their term. Although this democratic tool is on the rise worldwide and was supported in the past by influential figures such as Rousseau and Marx, its study has been neglected by contemporary political theorists. The aim of this contribution is to identify the main arguments for and against the use of recall mechanisms, and to assess both their normative and empirical validity. In particular, it asks whether they have the capacity to improve the quality of representation or at least the perception of representative institutions' legitimacy, and answers with a moderate "yes"-especially for the latter aspect (perceived legitimacy).

\section{OPEN ACCESS}

Edited by:

Romain Lachat,

UMR7048 Center de Recherches

Politiques de Sciences Po

(CEVIPOF), France

Reviewed by:

Raul Magni Berton,

Université Grenoble Alpes, France

Anthoula Malkopoulou,

Lund University, Sweden

${ }^{*}$ Correspondence:

Pierre-Etienne Vandamme pierre-etienne.vandamme@ulb.be

Specialty section:

This article was submitted to Elections and Representation,

a section of the journal

Frontiers in Political Science

Received: 01 May 2020

Accepted: 04 August 2020

Published: 25 September 2020

Citation:

Vandamme P-E (2020) Can the Recall Improve Electoral Representation?

Front. Polit. Sci. 2:6.

doi: 10.3389/fpos.2020.00006
Keywords: recall, representation, accountability, independence, trust, dissatisfaction, polarization

\section{INTRODUCTION}

Despite growing democratic resentment, several empirical studies reveal citizens' unwillingness to get rid of representative institutions (Fuchs and Klingemann, 1995, pp. 434-437; Ferrin, 2016; Clarke et al., 2018) ${ }^{1}$. Polls, however, frequently report that many citizens distrust their representatives and believe that they do not care about them. Thus, those who are not completely resigned would want representation to be improved, for example by giving citizens more control over their representatives (see Bedock, 2020 and Dolez, forthcoming, both in this Frontiers research topic). One possible mechanism of control, invoked for example by many Gilets jaunes in France (Bedock et al., 2019; Egger and Magni-Berton, 2020), is the recall-the possibility to remove elected representatives from office through a vote or petition before the end of their term.

The recall is an instrument dating back to the Roman Republic ${ }^{2}$, once praised by Rousseau (1762/2008) and Marx (1871/1972), and still used nowadays in several states, regions, provinces or municipalities, in different countries-especially Peru, the US, Japan, Poland, Columbia and Bolivia (Qvortrup, 2011; Welp, 2018; Welp and Whitehead, 2020). Perhaps as a result of increased dissatisfaction with existing representative institutions, recall practices are on the rise (either spreading to new levels of government or being introduced) in diverse political contexts, although this phenomenon seems to have passed "below the radar" of many analysts of democratization processes (Whitehead, 2018). Recently, the tool was even promoted in presidential campaigns in the $\mathrm{UK}^{3}$ and France ${ }^{4}$, institutionalized in a modest form

\footnotetext{
${ }^{1}$ See nonetheless (Tormey, 2015) on the diversity of movements contesting representative democracy.

${ }^{2}$ Although the practice of ostracism, in Athens, had some similarities with it (Cronin, 1989, p. 128; Tridimas, 2016; Malkopoulou, 2017).

${ }^{3}$ Before the 2010 election, all major political parties expressed support for the recall (Whitehead, 2018, pp. 1348-1349).

${ }^{4}$ During the 2017 Presidential campaign, 4 out of 11 candidates expressed their support to it (Whitehead, 2018, p. 1348).
} 
in the UK in 2015 (Tonge, 2019) and it is often praised by socalled "digital parties" such as Podemos or 5 Stelle (White and Ypi, 2020, 181-182).

Although it is often considered as an instrument of direct democracy (Cronin, 1989; Altman, 2010; Welp, 2018) it seems preferable to characterize it as an instrument of empowered representative democracy. It is not aimed at giving direct legislating or initiating power to citizens. It does not question the very idea of having representatives. Its aim is rather to improve representation-as Cronin (1989, p. 133) himself acknowledges-by making it more responsive to citizens' aspirations.

The aim of this contribution is to identify the main theoretical arguments for and against the use of recall mechanisms, and to assess both their normative and empirical validity ${ }^{5}$. More precisely, the research question is whether the tool has the capacity to improve existing representative institutions, either by increasing citizens' support for their political system or by improving the expected quality of democratic decisions. The second section introduces the mechanism, the different forms it can take, and its main purposes. The positive claims made by his defenders are systematically confronted to the available empirical evidence. The third section deals with the main objections challenging the capacity of recall mechanisms to improve representation-the value of independent representatives, the limits of majority rule, the risk of instrumentalization and polarization, the risk of permanent campaigning, and the harshness objection. These objections, I argue, warn against some uses of the recall and qualify its potential as a remedy for current challenges to representative democracy. However, I claim that they are not fatal to the proposal. Therefore, the fourth section briefly introduces different uses of this instrument with a potential to enrich existing representative institutions.

\section{THE PROSPECTS OF RECALL MECHANISMS}

Broadly defined as the possibility to remove elected representatives from office before the end of their term, the recall comes in many guises. Table 1 borrowed to Qvortrup (2011, p. 163), gives a clear preliminary picture, distinguishing recall from impeachment, and citizen-initiated from parliament-initiated recall.

What I will be concerned with, in this article, is the direct recall, thus initiated and decided by citizens. The procedure usually starts with a petition. If a defined threshold of signatures is reached, either a popular vote (also called "recall referendum" or "recall election," or "by-election") is organized (often with a required threshold of participation), or the representative is

\footnotetext{
${ }^{5}$ The empirical validity of arguments is assessed whenever there is reliable data available. This article, however, does not offer any new data. In contrast, the normative validity of a claim (such as the value of having independent representatives) is assessed in reference to widely accepted democratic norms such as political equality and the equal consideration of interests.
}

TABLE 1 | Typology of revoking mandates of elected representatives.

\begin{tabular}{llll}
\hline & \multicolumn{2}{c}{ Who initiates? } \\
\cline { 3 - 4 } & & People & Parliament \\
\hline Who decides? & People & Direct recall (e.g., California) & $\begin{array}{l}\text { Indirect recall } \\
\text { (e.g., Romania) } \\
\end{array}$ \\
\cline { 3 - 4 } & Parliament & $\begin{array}{l}\text { Citizen initiated } \\
\text { impeachment (e.g., Uganda) }\end{array}$ & $\begin{array}{l}\text { Impeachment } \\
\text { (e.g., US) }\end{array}$ \\
\hline
\end{tabular}

automatically recalled ${ }^{6}$. In such case, either new elections take place, or predefined substitutes automatically take the position.

Another version of the direct recall offers citizens a right to dissolve the whole assembly, as currently practiced in Latvia, Slovakia and in six Swiss cantons (Magni-Berton and Egger, 2019, pp. 81-82). This use, as we shall see, helps avoiding some of the problems associated with the individual recall, such as its strategic instrumentalization or its presumed harshness. It is also easier to use in PR systems. In what follows, I will mainly focus on recalling individuals, but I will come back to this collective recall later.

I will now introduce the main purposes of recall mechanisms and confront them to the empirical knowledge we currently have about their effects in a diversity of contexts. Obviously, this empirical knowledge is often very context-dependent and cannot be generalized without further question. Nevertheless, it provides interesting provisional ${ }^{7}$ insights about the validity of some arguments for and against the recall. Arguments against the mechanism are then explored in more depth in the third section.

\section{Arguments for Recall}

What are the main arguments in favor of the recall device? What benefits is it supposed to deliver? Let us start with the most interesting arguments put forward by Thomas Cronin's (1989, pp. 133-135) comprehensive study of so-called direct democracy mechanisms in the US. I will then add a new argument, based on trust and the symbolic benefits of the recall.

1. The recall provides for continuous accountability, so that voters need not wait until the next election to rid themselves of an incompetent, dishonest, unresponsive, or irresponsible public official.

Increasing citizens' "grip" on their representatives is the main purpose of recall mechanisms. Electoral representation is based on the assumption that voters should be able to get rid of unsatisfying representatives, and the recall is supposed to make this easier, thereby increasing the incentives faced by representatives to care about public opinion.

This argument sounds very plausible on paper. To the extent that elections can generate a form of accountability, more

\footnotetext{
${ }^{6}$ This is the case, for example, in British Columbia, if $40 \%$ of the voters sign the petition within 60 days (Qvortrup, 2011, p. 163).

${ }^{7}$ Provisional until the mechanism is tested in the context where the reform is considered, or in sufficiently comparable contexts.
} 
frequent opportunities to sanction elected representatives should increase accountability. What is more, candidates sometimes lie and voters sometimes make mistakes; it therefore makes sense to provide voters with an effective tool to correct their errors of appreciation (Bowler, 2004, p, 204).

However, several scholars have questioned the capacity of voters to effectively hold their representatives accountable for actions engaging their responsibility. In most democracies, voters have been found to be largely ignorant about the work (or even identity) of their representatives (Somin, 2013; Brennan, 2016; Achen and Bartels, 2017) ${ }^{8}$. Most of them also face profound difficulties "in connecting specific policy proposals to their own values and interests" (Bartels, 2008, p. 27). Therefore, they are often not properly equipped to judge their representatives' policy choices. What is more, they usually "have great difficulty making sensible attributions of responsibility for hard times" (Achen and Bartels, 2017, p. 304) $)^{9}$ or even to assess whether times have been good or bad during a term in office. As a result, when voters do vote retrospectively, they often seem to reward or sanction representatives for things they are not responsible for, such as droughts, floods or a suddenly changing economic dynamic in the months preceding an election (whatever the economic results of the whole term in office).

Nevertheless, the fact that citizens lack relevant information when they vote is not fatal to electoral accountability. As Achen and Bartels (2017, p. 318) themselves recognize, reelectionseeking politicians will at least "strive to avoid being caught violating consensual ethical norms in their society." Clear cases of corruption, partiality or misbehavior will usually be reported by the media and sanctioned. What is more, elected politicians usually ignore the extent to which electoral accountability is defective. Thus, the mere threat of sanction might influence them even if citizens do not sanction effectively. Therefore, to the extent that the availability of recall constitutes a serious threat, accountability could be increased by it.

In practice, the evidence that the availability of recall mechanisms leads to more responsiveness and accountability is not clearly established. One reason is that the mechanism is not used much, even when available, which reduces the threat faced by incumbents. Thus, for example, Bowler (2004, p. 208) reported that only $10 \%$ of municipalities with the recall in the US had witnessed recent attempts at recall. What is more, most of the attempts do not lead to a recall referendum (Welp, 2018, p. 456), either because the threshold of signatures is not reached or because the targeted candidate resigns to avoid public humiliation. This does not mean that the availability of recall has no effect on representatives, but it means that it is hard to measure at this stage and that we cannot assert with full confidence that it will be effective, if introduced in a new context. We should have modest expectations in this respect,

\footnotetext{
${ }^{8}$ Although the studies these authors draw on are often one-sided (Lupia, 2006) and some of their claims have been aptly refuted (see for example Christiano, 2017 or Chambers, 2018), it remains quite uncontroversial that many voters are not sufficiently informed to properly play their monitoring role.

${ }^{9}$ Especially in contexts with coalition governments and multilevel governance (Anderson, 2000).
}

at least until wider experimentation provides us with more scientific evidence.

2. The recall helps check undue influence by narrow special interests.

When introduced in the US in the early 20th century, the recall was explicitly conceived as "a means of bringing some honesty back into politics" (Bowler, 2004, p. 203). Is it a realistic expectation, though? If the problem is that money pervades politics, recall may not be the solution, as campaigning for recall is costly as well, and special interest groups may instrumentalize the recall to private ends (see Garrett, 2004; Campodonico, 2016). As brought to attention by Cronin (1989, pp. 90-124) and others, promotors of direct democracy mechanisms have often underestimated the influence of money on initiatives and referendum campaigns. Yet whatever applies to I\&R campaigns may apply to recall campaigns as well.

Empirically, though, it is not clear whether compared to policies enacted through traditional representative procedures, popular initiative referendums are better aligned with the preferences of the majority or more vulnerable to capture. Gerber (1999) and Matsusaka (2004), for example, defend the former view in the US context, but Lax and Phillips (2012), studying the same context, saw no correlation between the availability of direct democracy instruments and responsiveness to majority preferences. Beyond the US, though, scholars of direct democracy seem less pessimistic about the capture of popular initiatives by the wealthy (Altman, 2010, pp. 189-190). In any case, general considerations about this are bound to be somewhat speculative. The risk might be highly context-dependent.

Nevertheless, whether or not they are properly and effectively used in practice, recall mechanisms increase voters' opportunities to control their representatives-and hence potentially to check undue influence. Given that there is no apparent reason to expect a higher influence of private lobbies with recall than without, absent countervailing reasons we would have reasons to support this device, based on its empowering potential. Then, it is the media's role to report misbehavior and breach of promises, and it is the citizens' role to pay attention and mobilize when it proves necessary.

Besides, to reduce the risks of "capture" of recall initiatives, it seems reasonable, as suggested by Cronin (1989, p. 154), to "require sponsors of a recall, through their treasurer, to file documents listing those who contributed to their effort, as well as expenditures."

3. The recall enables jurisdictions to permit their officials to serve longer terms.

This argument is interesting insofar as it responds to two objections frequently addressed to the recall. First, it is costly, as popular votes are organized more frequently. Second, it creates a state of permanent campaigning (an objection to which we shall come back later). However, if the introduction of recall goes with an extension of the terms if office and if recalls are not too frequent, the cost might not be excessive. And more importantly, elected representatives keeping the support of their constituents 
would be able to widen their time-horizon, which is not negligible considering the current environmental crisis.

There is no empirical indication, however, that the introduction of recall is usually associated with an extension of terms. And in cases where both measures would be combined, there would be a trade-off between a recall procedure too easy to enact, which would create permanent campaigning, and a procedure too difficult to enact, which might reduce the potential for accountability.

4. The recall offers a safety-valve mechanism for intense feelings.

It is part of the nature of elections to create hope, and then to generate disappointment (Przeworski, 2018). And when disappointment is high, it can be very frustrating for voters to wait until the end of the term to be able to cause effective change. The alternative, then, is popular protest, taking the street and often hopelessly pressuring the government for a change in its policy orientation-actions generating risks of conflict and political instability.

Judged from this perspective, the recall certainly looks promising as a channel or an outlet for popular frustration (Lijphart, 1984), provided that the tool is generally known, which is not always the case (Welp and Whitehead, 2020, p. 9). Lenin himself asserted that the right of recall would have made a violent revolution unnecessary in 1917 (see Qvortrup, 2020, p. 39)!

This pacifying effect, however, is not guaranteed-and it is highly context-dependent (Whitehead, 2020, p. 238). Some uses of the recall could actually increase political conflicts. As we shall see, we should not be blind to the possibility of partisan instrumentalizations of the mechanism. If the main effect of the recall was to provide a tool for poor losers to contest elections result, the democratic gain would not be clear (Welp, 2016; White and Ypi, 2020). Frequent recalls might then lead to polarization and mutual hatred between opposing parties, provoking "spirals of ever more vitriolic recall campaigns" (Bowler, 2004, p. 207) and disincentivizing loyal opposition. We will come back to this in section The Risks of Instrumentalization and Polarization.

5. The recall might increase trust in the representative system.

This argument might come as a surprise. Some might expect the recall to create an atmosphere of permanent suspicion toward representatives, with the result of reinforcing distrust. By institutionalizing an additional mechanism to sanction representatives, are we not sending the message that the public is right to be suspicious, to mistrust elected politicians (Bauer and Fatke, 2014)?

First, we should draw a distinction between different dimensions of trust:

- Trust in the political system in general (or regime trust), which includes not only elections, but other aspects of democracy as well, and can be measured through opinion polls.

- Trust in the electoral representative system, which can be partly measured through turnout to elections (and partly through polls).

- Trust in the political class, again measurable through polls.
The effect that the recall may have on regime trust is an empirical question that remains largely open and whose answer partly depends on the particular combination of recall mechanisms with other institutions in a given context. However, consistently with what has sometimes been found about the initiative and referendum (Gherghina, 2017), empowering citizens with a new tool for political action may increase regime trust.

More important for this research topic is the issue of trust in the electoral representative system. This question is also very uncertain, but we have some empirical indications to draw on. First, from what we know about the practice of recall in the US, it seems that it reinforces trust in the electoral representative system, as expressed by levels of turnout (Qvortrup, 2011, p. 168), contrary to what has sometimes been found about citizen initiatives and referendums (Dyck, 2009; Bauer and Fatke, 2014; Peters, 2016). This result should be tested in other institutional contexts, but I see some reasons to expect a positive effect on this specific kind of trust as well.

As mentioned in the introduction, although the recall is often presented as an instrument of direct democracy (Cronin, 1989; Altman, 2010; Welp, 2018), it does not question the principle of representation (in contrast with initiatives and referendums). And it does not question electoral legitimacy (in contrast with sortition). What it does is questioning a certain understanding of electoral representation (Bowler, 2004; Whitehead, 2020)based on blind trust and the relative independence from public opinion. Yet given that many citizens are unsatisfied with that model of representation and would value more control over their representatives (see again Bedock, 2020 and Dolez, forthcoming in this Frontiers research topic), the availability of recall mechanisms is likely to increase citizens' satisfaction with their representative institutions. Citizens might gain a sense of popular power and control over their representatives, potentially increasing trust in the ability of elections to generate adequate representation.

The benefits of the recall, in this case, are mostly symbolic: it may alter the perception of the representative relationship in a desirable way. Without the recall, the assumption seems to be that citizens choose their preferred elites and then must wait patiently for the next election, where these elites will try to seduce them again. With the recall, the representative relationship becomes somewhat less hierarchical. It appears more clearly that representatives are agents of the people and cannot allow themselves to betray the confidence conferred to them by the election. As any employee, they can be fired at any time if their work is judged unsatisfying or if they commit a professional fault ${ }^{10}$. From this perspective, whether or not the availability of recall is sufficient to secure increased accountability and responsiveness to majority preferences, it could be valued by citizens and it could improve their perception of electoral representation. As seems to have been the case with the practice of ostracism in Athens (Forsdyke, 2005; Malkopoulou, 2017, p. 632), what matters in this case is not so much the frequent use of the mechanism, but its availability - a symbolic reminder that

${ }^{10}$ This argument is borrowed to Gilets jaunes members interviewed in Bedock et al. (2019). 
representatives could be removed at any time and that citizens hold the reins.

Consistently with this, though, trust in the political class may diminish. This could happen, for example, if citizens fail to appreciate the diversity of constraints faced by governments. If they systematically sanction their representatives for failures to deliver on some expectations that they simply cannot meet, the mechanism could then turn out to be unable to support trust in electoral representation. In other words, if citizens keep recalling representatives without seeing any improvement, they might end up losing faith in elections (and recalls).

Yet a benefit of the recall, in this respect, might be to encourage elected politicians to be clearer about these constraints and how they deal with them. The increased risk of sanction should incentivize them not to promise the impossible and to take the necessary time to justify themselves publicly when they have failed to honor some promises for reasons beyond their control. Again, the effect on trust might turn out to be positive. Yet this remains to be checked empirically.

\section{Taking Stock}

The main purpose of the recall is to strengthen representatives' accountability toward citizens and thereby to make them more responsive and less vulnerable to undue influence. In addition to this, it may make it easier to extend terms in office, and more importantly, it may provide an alternative channel for citizens' frustration and generate more trust in the electoral representative system.

There is no clear empirical evidence that all these benefits will necessarily result from institutionalizing recall mechanisms. Nevertheless, what can reasonably be expected is that citizens would be satisfied with the availability of an additional tool of expression and that this tool may increase accountability and responsiveness on the long run if it is sufficiently used.

It is too early, however, to conclude that the recall improves electoral representation. There are several important objections that need to be considered, including objections to the very idea of strengthening accountability on which support for the recall is usually based.

\section{OBJECTIONS}

When the first representative governments were created in Europe and the USA, it was decided explicitly not to use recall mechanisms in order to guarantee the independence of representatives, who were thought to be better positioned to judge in the name of the people, in light of circumstances sometimes unknown by citizens, what policies would serve the public interest (Manin, 1995) ${ }^{11}$. The first objection I would like to discuss is therefore the one grounded on the value of independence for representation. I will then consider a connected theoretical objection-the moral constituency objection-against the idea of increasing accountability to a specific constituency. Then, I will come to more practical objections, pointing

\footnotetext{
${ }^{11}$ Although James Madison once expressed support for this tool (Whitehead, 2018, p. 1345).
}

respectively to the risks of instrumentalization, polarization, and permanent campaigning. Finally, I will consider the harshness objection, suggesting that the prospect of public recall may turn some quality people away from politics.

\section{The Value of Independence}

The relative independence of representatives is one of the distinguishing features of modern representative governments (Manin, 1995). The thought being that elections would bring to power those who distinguish themselves from the mass, who are in some respect superior to ordinary citizens, it appeared important, at the time of creation of these new regimes, not to tie the representatives' hands too much. The imperative mandate model, where representatives receive clear and legally binding instructions from their constituents and can usually be recalled if they deviate from these instructions, would have canceled the epistemic benefits of delegating political power to those among us "whose wisdom may best discern the true interest of their country, and whose patriotism and love of justice will be least likely to sacrifice it to temporary or partial considerations" (Madison, 1787, pp. 56-57). Thus, representative governments were largely based on an elitist understanding of representation. There is however a diversity of arguments that can be provided in favor of the independence of representatives, which are not all based on such elitist premises.

The relative independence of elected representatives has historically been defended for four main reasons (Pitkin, 1967; Manin, 1995; Przeworski et al., 1999; Urbinati, 2006):

1) If conditions (economic, social, political) change during the term in office, it is important that representatives have the freedom to adapt their actions and are not strictly bound by promises made under different conditions.

2) Representatives are sometimes in a better position than constituents (not because they are wiser, but because of their full-time investment in the task) to assess certain needs or constraints. For this reason, there is an epistemic gain in giving them some leeway ${ }^{12}$.

3) The independence of representatives is crucial for the fairness of democracy in that it allows for the equal consideration of opinions. If representatives were bound by imperative mandates, the power of the majority would be strengthened at the expense of minorities (Kelsen, 1929). However, the role of representatives is not to strictly represent the interests of their electors. They probably have a moral duty to make fair decisions, considering all affected interests. Thus, here again there is a potential epistemic gain in granting them independence, but in a normative sense [increased fairness rather than accuracy of decision as in (2)].

4) With an imperative mandate, there is no longer any possibility of deliberation in parliament or negotiation, which can block decision-making processes (Urbinati, 2006, pp. 131-132).

For these reasons, it is often thought that representatives must be legally independent (from the will of their voters), but politically

\footnotetext{
${ }^{12}$ This idea probably goes back to Edmund Burke and was also defended by
} Madison, Paine and Sieyès. 
dependent on the influence of public opinion (and not merely the opinion of the majority). This is why their independence is relative: as Pitkin $(1967, \S 7)$ explains, representatives are not supposed to act completely independently of the will of those they represent. Their actions must generally comply with this will and deviations from it must be justified-by one of the reasons stated above for example.

How should we assess these arguments in light of the contemporary challenges to electoral representation? The first point seems hard to deny: voters simply cannot fully know, at the time of selection, what kind of decisions their representatives will have to deal with. They can anticipate some of them for sure, but not everything that might happen. Therefore, some degree of flexibility and thus independence is practically required.

The second argument is less obvious. The elitist version relates to Madison and Sieyès' assumption that the elected will be (somewhat) superior to the mass. The non-elitist version points to a positional (rather than intrinsic) advantage: elected representatives may not be smarter or wiser than voters, but their daily involvement in politics gives them a privileged epistemic viewpoint. They might for example have a better appreciation of political and economic constraints, overlooked by many citizens. They might be better informed, because they have strong incentives to follow the news and they are usually surrounded by all sorts of advisors ${ }^{13}$.

It seems to me that these positional advantages are credible. The strength of the argument should however be qualified. Firstly, because it will often be the case that some experts or citizens are better informed or better placed to make a judgment on a particular issue than politicians. Hence, the positional advantage is not absolute. They might just, on average, be better placed to judge some issues than ordinary citizens. Secondly, the argument must be qualified because elected representatives will also suffer from important positional (and epistemic) disadvantages:

- Given that elections tend to favor people with a certain socio-economic status (Bovens and Wille, 2017), elected representatives might not know what it means to be an unemployed person, a refugee, a poor worker, a single mother with a low income, etc. Thus, they do not have direct access to these disadvantaged standpoints.

- Given that elected representatives tend to be socialized in similar contexts, they might develop biased views which are widely shared among their peers, without being sufficiently exposed to alternative views.

It is therefore important that representatives enjoy some degree of independence from public opinion. Nevertheless, keeping in mind the risks of biases, it seems equally important that they are kept in check by citizens.

The third argument faces a similar limitation: independence theoretically allows for an equal consideration of the affected interests, but it also leaves room for biases. If we abandon elitist assumptions about the higher wisdom of the more educated,

\footnotetext{
${ }^{13}$ This seems to be in line with the way many politicians perceive themselves (compared to citizens). See Schiffino et al. (2019).
}

there is no guarantee that elected representatives will be more public-spirited or other-regarding than ordinary citizens. In a way, elected representatives are just ordinary citizens with a strong interest in politics and special traits favorable to election, such as charisma and communication skills. Yet they remain affected by the same biases as other citizens, they have interests of their own and they are as corruptible as anyone placed in a position of power. Thus, we should not assume that the independence of representatives will necessarily increase fairness. What is nonetheless true is that strict majority rule is no guarantee of fairness either-a point to which I come back in section The Moral Constituency Objection.

Finally, the fourth argument is particularly strong. The need to be able to make compromises (and thus to sacrifice some electoral promises) is particularly important in contexts of coalition governments (Manin, 1995, pp. 272-273). But it also matters more generally, in all contexts, because elections are not the only vector of popular will. Thus, it is also desirable to have a government willing to make compromises with other kinds of representatives, be it in negotiations with unions or as a response to popular protest movements. Independent representatives facing an independent public opinion allows for more dynamic representative relations. Winning elections is usually not considered as an authorization to do whatever was promised, at any cost, without any room for popular resistance. If we want to reduce the risks of a tyranny of the majority, deliberative interactions with actors of civil society appear particularly important. And an imperative mandate would make these deliberative interactions impossible.

All these arguments, properly qualified, point to the necessity of some degree of independence. They therefore make imperative mandates normatively unattractive. However, they leave open the question of the exact degree of independence that should be enjoyed by representatives. And an important point to make is that the recall, contrary to the imperative mandate, is compatible with some degree of independence (see also Malkopoulou, 2016, pp. 310-311). The key difference is that the imperative mandate "explicitly specifies the criteria to launch a recall process" (Egger and Magni-Berton, 2020, p. 51). For example, if they fail to implement policy $\mathrm{x}$ or to address issue $\mathrm{y}$, they should be recalled. In contrast, when the recall is dissociated from any imperative mandate, representatives potentially have more room for maneuver. They could be sanctioned for things that were not explicitly mentioned in an electoral "contract," but they also have more freedom to defend themselves, to argue with their constituents and to try to convince them that they are doing a good job.

I see at least two reasons why the recall and the imperative mandate are often conflated. First, it is hard to institutionalize an imperative mandate without the recall (yet the opposite is conceivable). Second, in the socialist tradition, the recall has been defended as a way of securing imperative mandates (Campodonico, 2016; Qvortrup, 2020). The link, however, is not necessary. We could conceive the recall as a tool that allows citizens to decide how much independence they want to grant to their representatives. By electing them, voters would give their representatives some leeway, but they would keep the 
power to decide when this trust has been abused, when the representatives have to justify their actions properly or must face a recall referendum. Thus, being compatible with some degree of independence, the recall is not disqualified by the four arguments considered above.

The question, then, is whether the degree of independence enjoyed by representatives in democracies without the recall can be considered as satisfactory. There are at least two ways of assessing this. One is to consider whether citizens are generally happy with the way they are represented. Yet the starting point of this article was precisely the widespread dissatisfaction with existing representative institutions. From citizens' viewpoint, then, even if several groups are happy with how they are represented, the independence enjoyed by representatives may look excessive to most. Citizens may of course be wrong about this, so it is worth also asking more objectively whether their preferences usually translate into policies. And the evidence about this is also quite negative: we can observe throughout wealthy democracies a "highly unequal distribution of political influence, with policy-makers responding powerfully to the preferences of affluent citizens but not at all (or even negatively) to the preferences of poor citizens" (Bartels, 2017; see also Bartels, 2008 and Gilens and Page, 2014 for the US more specifically; Rosset and Stecker, 2019 for the European context). The formal independence from public opinion enjoyed by elected representatives does not mean that their judgments will be independent from any external pressure, as we expect from judges for example. The fact is that elected representatives are heavily influenced in their decisions by lobbies, bureaucrats, businesses, civil associations, media and polls (White and Ypi, 2020, p. 195). And this influence is highly unequal, as also reflected by the effects of contributions to electoral campaigns and political parties on electoral results (Cagé, 2018). People are therefore not entirely being paranoid when they claim that their representatives do not care about what they want. Even if costless promises are usually honored $^{14}$, there is strong evidence showing that, for a diversity of reasons which it is not the place to study, majority preferences over key redistributive issues are usually neglected, to different degrees, in most if not all affluent democracies. It is judged from this perspective that the prospects of increased accountability to the majority that the recall potentially offers seem desirable.

\section{The Moral Constituency Objection ${ }^{15}$}

The majority's degree of satisfaction, however, is not the only criterion based on which democratic decisions should

\footnotetext{
${ }^{14}$ Empirical research in several political contexts shows that political representatives usually try to honor their promises (Naurin, 2011; Thomson et al., 2017; Guinaudeau and Persico, 2018, p. 236). What matters, however, is not only the proportion of promises that are honored, but also the intensity of popular preferences for some promises which are seldom honored, such as raising low wages or taxing the wealthy.

${ }^{15}$ White and Ypi (2020) discuss a distinct "constituency objection," from which I take inspiration here, but which is targeted at their preferred model-intra-party recall-and blames it for tying representatives to their partisan constituents at the expense of the rest of their constituents-the whole people.
}

be evaluated. One of the arguments for the independence of representatives from public opinion was based on fairness and the necessity to represent minorities as well. If representatives become so to speak "slaves" of the majority, the minorities are clearly at risk. Yet, morally speaking, representatives are not supposed to ignore the minorities.

Although imperative mandates would make it impossible for representatives to deviate from majority preferences, the recall, being compatible with a free mandate, is also compatible with a "recursive" representative relationship (Mansbridge, 2019), characterized by deliberative interactions between representatives and their constituents. It remains possible for representatives to try to convince voters to trust them, to explain their controversial choices and potential breaches of their electoral promises. Nothing in the recall is meant to cancel these deliberative interactions ${ }^{16}$. Thus, representatives would still have the freedom to take account of minority preferences and convince the majority that it is the right thing to do. Yet even taking this view of representation, it remains true that representatives have no right to force voters to accept the consequences of their convictions (Cronin, 1989, p. 150). Therefore, if they fail to be persuasive enough, the recall remains democratically legitimate.

A parallel argument could nonetheless point out the fact that, morally speaking, voters are not the only people elected representatives should care about. Other "moral constituents" that are not enfranchised include children, future generations, and more generally all the parties potentially affected or coerced by the representatives' decisions (Gutmann and Thompson, 1998; Benhabib, 2004; Goodin, 2007).

From this perspective, the worry is not so much that the recall would potentially bring representatives closer to the median voter's preferences. After all, there are no reasons to believe that minorities, in a specific constituency, will care more about the interests of outsiders and future generations than the majority. The worry is that by reducing the margin of independence of representatives, we would increase their ties to their political constituency, at the expense of other members of their moral constituency.

As argued before, there is no ground to believe that representatives will usually use their freedom to deviate from majority preferences in order to promote policies that benefit vulnerable foreigners or future generations. The argument has nevertheless some plausibility, for it does happen that representatives make morally justified decisions against the wishes of the majority of voters. Think about welcoming refugees, for example. We would not want to make it more difficult than it already is for representatives to rightly consider the interests of third parties when making decisions. The interesting empirical question here is whether there is any evidence that elected representatives care on average more about these unenfranchised affected parties

\footnotetext{
${ }^{16}$ They could even be increased if the recall was accompanied with a public hearing of both sides and a demand to recall initiators to specify their charges in order to allow the accused public officials to defend themselves (Cronin, 1989, p. 154).
} 
than the median voter, and whether that translates into policy choices.

The strength of this objection will heavily depend on this open empirical question. What the objection brings to light, in any event, is the limits of trying to improve democratic institutions by strengthening the grip of the majority. There are good reasons to trust the majority as a general rule (Estlund, 2008; Landemore, 2013; Goodin and Spiekermann, 2017). These reasons make it preferable to have collective decisions aligned with the preferences of the median voter rather than those of the wealthy, for example. However, governments make decisions that heavily affect the interests of third parties-foreigners and future generations in particular. And if we care about improving the fairness of those decisions, we will have to complement majoritarian institutions with others capable of bringing in collective deliberations the perspectives of outsiders. This, of course, goes beyond the scope of this article, but it helps recognizing the limits of the considered reform.

\section{The Risks of Instrumentalization and Polarization}

If we accept the theoretical arguments for trying to strengthen representatives' accountability through recall mechanisms, we still have to consider possible adverse effects of the instrument. The first risk to be taken seriously is that of instrumentalization of the recall by the opposition. Although citizens are supposed to be the initiators of a recall process, it is impossible to exclude opposition parties to influence the process in order to bring down an opponent. Even if they cannot formally initiate it, it would be easy for them to motivate citizens to do it, and then to support the recall in public debates. This is not necessarily a problem, because a recall procedure would still need to be largely supported by citizens to be successful. The risk, however, was briefly mentioned in the second section: we would not want the recall to be a tool for poor losers to systematically contest electoral results. Systematic recalls, rather than offering a safety-valve for intense feelings, might lead to polarization and mutual hatred between opposing parties, disincentivizing loyal opposition.

The empirical evidence about this is mixed. As Bowler (2004, p. 209) puts it, all recall elections are probably "a mixture of genuine grievance and spite." Yet analyzing 62 recall elections between 1998 and 2002, he found that the majority were driven by disputes over policies (45\%) or allegations of corruption or malfeasance (17\%) rather than personal grudges $(15 \%)$. In Peru, however, recall initiatives seem to have been more widely instrumentalized by coalitions of poor losers (Welp, 2016), which can generate a lot of frustration for the legitimate winners. Welp suggests that it results from two factors: (1) the comparatively high probability of success of Peruvian recall procedures, due to their procedural design; (2) the fragmentation of the partisan landscape (at the local level).

What could mitigate the temptation of instrumentalization is the finding that recall initiatives often result in the strengthening of the incumbent's position if he or she wins the recall referendum (Qvortrup, 2011). Considering this, opposition parties may be careful, as they sometimes are with impeachment procedures.
If one nevertheless wants to minimize the risks of inappropriately motivated recalls, a possibility is to empower a public body to assess the validity of the reasons supporting the recall initiative, as is the case for example in Minnesota (Bowler, 2004, p. 203), Ecuador (Welp, 2018) or Romania (Campodonico, 2016, p. 366). The assessment could be made by judges, as is usually the case, or a randomly selected citizen jury. In any case, it can be judged desirable to ask those starting the initiative to provide a justificatory statement, as in British Columbia (Qvortrup, 2011, p. 165). Channeling intense feelings may be desirable, but not any intense feeling is a legitimate motive for recalling representatives ${ }^{17}$.

Furthermore, to reduce the polarizing potential of recall procedures and make them more deliberative, some regulations are conceivable, such as requiring a public hearing of both sides and a "cooling-off" period between the end of the petition and the vote (Cronin, 1989, p. 154; Whitehead, 2020, pp. 241-242), during which the targeted representatives could abrogate an unpopular law, deliver on a popular promise or try to justify themselves and regain confidence.

The risks of instrumentalization and polarization should not be overlooked, but they need not be fatal to the proposal. If they are taken seriously enough, some procedural arrangements (as just indicated) may make these adverse effects less likely to occur.

\section{The Risk of Permanent Campaigning}

Another risk is that the availability of recall mechanisms would create a state of permanent campaigning (Bowler, 2004, p. 205; Welp, 2018, p. 461). It also seems to be the case in Peru (Welp, 2016), for example. And it is worrisome because elected representatives need time to act. Policymaking takes time, especially when it involves negotiations with different actors. Thus, if recall initiatives closely follow elections, or if representatives are continuously worried about the possibility of being recalled, it might become impossible for governments to rule effectively. What is more, rulers would have incentives to favor short-term results over the long term, which is not desirable if one considers the importance of protecting the environment or to make social investments, for example, whose benefits are not immediately identifiable and for which rulers may not have the possibility to claim credit during their time in office.

Considering this risk, recall procedures should not be too easy to enact-a point against "liquid democracy" (see Blum and Zuber, 2016), which enables citizens to recall their delegates at any point in time through technological means. There are different ways to make of the recall a last resort option rather than the norm, like increasing the threshold of signatures needed to initiate the process or reducing the number of acceptable motivations for a recall.

Furthermore, it would make sense to forbid recall initiatives in the first 2 years of a mandate, as is the case in several countries, to make sure that those who won the election have some time to act on their electoral promises and do not spend their time

\footnotetext{
${ }^{17}$ In particular, this could help reducing the risks of instrumentalization of the recall to exclude from politics minority groups suffering from hostile prejudices, such as ethnic minorities. On this risk, see (Malkopoulou, 2016), pp. 314-315.
} 
campaigning. Finally, as suggested above, we could imagine coupling the introduction of the recall with an extension of terms. In that way, the short-term would be less privileged, but citizens would not lose control over their representatives (provided that the recall is not impossible to enact either).

\section{The Harshness Objection}

A last objection that I would like to consider points to the fact that people might become more and more reluctant to run for public office if they have to fear the humiliating prospect of a public recall (Cronin, 1989, pp. 136-137). This is largely an empirical question, for which there is no clear available evidence so far (Welp, 2018, p. 460). It nonetheless raises two interesting normative sub-questions.

First, to what extent is it desirable to make public office attractive? One might think that as long as there are enough candidates for elections to be competitive, the attractiveness of public office is sufficient. The risk, however, if it is not very attractive, is to attract only some specific categories of candidates: hard-skinned, self-confident, fascinated by power. If the overall aim is to improve representation, this might be a problem. Electoral representation already suffers from a lack of social and cognitive diversity. Even without adhering to the conception of parliaments as "mirrors" of society, there are good reasons to prefer a diversified pool of representatives than a relatively homogeneous one. First, it increases the potential of identification of citizens with their representatives, and therefore possibly the perceived legitimacy of the latter. Second, it reduces the risks of biased decisions-decisions involuntarily ignoring some perspectives and privileging some social categories (Vandamme, 2020).

Second, is there a qualitative difference between not being (re)elected and being recalled? After all, candidates already face the potentially humiliating prospect of a very low electoral score. Would things be very different with a recall mechanism? What makes it potentially more humiliating is the fact that a representative's performance is not judged among many others, as is the case in legislative elections for example. The representative exposed to a recall procedure faces an individual public trial, probably with increased media attention. It does not change much compared to a presidential reelection, but compared to legislative elections (in PR systems in particular ${ }^{18}$ ), it does. Thus, introducing a recall mechanism might not dissuade people to run for the presidency, but it might take away people who would have been tempted by a less exposed public position such as MP or member of a local council.

Two arguments can nonetheless be presented in favor of harshness (at least in some cases). First, as highlighted by Rosanvallon (2015, pp. 373-379), public officials who abuse their power for private benefits do not only breach a professional duty; they also harm democracy by contributing to the disrepute of the political class. Harsh sanctions might then be justified by the need to protect democratic representation. Second, if one considers politics as a profession, the mandate could be compared to an employment contract with a fixed term, citizens as a whole being

\footnotetext{
${ }^{18}$ I come back to the distinction between majoritarian and PR systems in section Would it Work in PR Systems?
}

the employer, paying politicians' wages-an argument we briefly considered in section Arguments for Recall. The fact that a term has been fixed does not impede employers to fire their employees if they consider their work as insufficient, and certainly if they have committed a professional fault. Thus, why should we think that the recall is too harsh when most citizens daily face the threat of dismissal in their professions? The public character of the sanction might be a difference, but there are other differences that make dismissals harsher for most citizens than for politicians, such as the difficulty of finding new employment and the lower unemployment benefits they are on average entitled to. Thus, we come back to the question of whether public office should be made more attractive than average jobs-a question which is also at the core of public debates about politicians' remuneration and is beyond the scope of this article.

To conclude, there might sometimes be a trade-off between making public office attractive and making public officials accountable (pending empirical confirmation). This does not suffice to reject the recall, however, as its drawbacks must obviously be balanced with its benefits. Besides, the collective version of the recall-recalling the entire assembly-is immune to this problem.

The harshness objection, however, might be more powerful in the case of randomly selected representatives, as in citizen assemblies (Vandamme and Verret-Hamelin, 2017, pp. 15-16). One reason is that these randomly selected people, compared with candidates in elections, have not asked to be publicly exposed. The other is that these citizen assemblies are supposed to be much more descriptively representative than elected ones, because social and cognitive diversity is one of their main added values and justifications. Hence, making the position attractive matters even more.

\section{Taking Stock}

None of the objections discussed above seems fatal to the proposal. The recall does not suppress the independence of representatives; it is compatible with a recursive form of representation; it can be designed in a way that reduces the risks of instrumentalization, polarization and permanent campaigning; and although it may make public office less attractive to some people, this is unlikely to counterbalance its expected benefits.

As suggested by Whitehead (2018, p. 1346), perhaps "the recall is most useful when it is known to be available, but thought not to be needed." Considered as a last resort option, the recall may not be necessary if representatives pay sufficient attention to their constituents' wishes and behave ethically.

\section{POTENTIAL USES}

Although the objections are worth keeping in mind, because they qualify our assessment of the recall, there are thus sound theoretical arguments in favor of it, some of them backed up by empirical evidence. Yet what are the most interesting uses of the recall? Who should face the prospect of recall, and who should be allowed to initiate a recall procedure? The choice between the different possibilities will be highly context-dependent, but I would like to end with a brief overview of the options. 


\section{Who Could Be Recalled?}

The most common use of recall mechanisms is at the local level. However, there are no theoretical reasons to limit it to that level of government. President Hugo Chávez, in Venezuela (2004) and President Evo Morales, in Bolivia (2008) survived attempts at (respectively direct and indirect) recall, while President Traian Basescu, in Romania (2012), was removed from office after an indirect recall-an impeachment confirmed by a recall referendum (Welp, 2018, p. 458). Thus, the direct recall of an elected president, also introduced in 2019 in Mexico (Whitehead, 2020), is perfectly conceivable. The risks of polarization in case of frequent uses might be higher, but the tool could be valuable as a last resort instrument (as is the case with impeachment). What is more, it is usually at that level of government that the political frustration is the highest and that a safety-valve mechanism to channel this frustration might be the most welcome. As highlighted by Rosanvallon (2015, p. 20), with the current shift of power from the legislative to the executive witnessed in most democracies, the control of the executive by the society becomes the key issue. What is more, because the election of a single person does not provide the "representative correction" that comes with the election of a whole assembly (Rosanvallon, 2015, p. 160), because the risk is thus higher of having a population that does not recognize itself in its highest representative, the need for proper accountability appears particularly important.

In theory, elected representatives facing the prospect of recall could include the Mayor, the Governor, the head of government, but also members of the City council, members of Parliament or even ministers (at least when they have been elected).

Recalling heads of local, regional or national government might seem more intuitive than local councilors or MPs, as the former clearly have public visibility and a special responsibility. Nevertheless, it often happens that MPs face scandals and yet cannot be (or are usually not) sanctioned by their peers. The prospect of recall by the whole constituency might help keeping them in check as well. It is quite unlikely to see a massive popular mobilization against a MP, as would be the case against a Mayor or President, but the threshold of participation could be lower for MPs.

In the case of ministers, the recall might serve to express popular protest against very unpopular policies. The government would not fall each time a policy is rejected by voters, but recalling a minister could be a signal that the government is expected to change its plans. In such cases, however, abrogative referendums might be preferable ${ }^{19}$. The latter have the advantage of being less ad personam. We could nonetheless imagine allowing abrogative referendums and keeping the possibility to recall the government for cases of extreme discontent, when it is not a matter of one or two policies anymore, but a definitive breach of trust between a government and the majority of citizens.

\section{Would It Work in PR Systems?}

Is the recall applicable across electoral systems? The received wisdom is that the individual recall is only relevant in plurality and majority electoral systems, "because it requires

${ }^{19}$ I thank Maija Setälä for this suggestion. that each representative's constituents can be clearly identified" (Lijphart, 1984, p. 200). However, it seems to me that the mechanism is conceivable (although more challenging) in proportional representation systems as well (certainly for ministers and possibly also for MPs). And some might see it as desirable considering that accountability is usually more difficult to secure with coalition governments where parties blame each other for failures or unpopular decisions (Anderson, 2000; Shapiro, 2016, p. 175).

Two things would change, however, compared with the majoritarian use. First, a candidate could be elected by a set of voters and recalled by a totally different set. For example, we could imagine a Green pro-immigration candidate being recalled through an initiative stemming from the far right and supported by voters from the right and center, none of which having voted for her in first instance. Thus, under such system, elected officeholders might face new incentives to be more consensual, to protect themselves from major hostility. This would add a sort of majoritarian dimension to PR systems. In order to minimize the risks of recall, representatives from radical parties would probably have to moderate their discourses. The result could be a reduction of political diversity and more convergence toward the center-a loss of some benefits of PR systems. Alternatively, one could see the recall in PR systems (and beyond) as a tool allowing for democratic self-defense against extremist parties or candidates (Malkopoulou, 2016). Yet being at one extreme of a political field does not necessarily mean being antidemocratic or harmful ${ }^{20}$. So, it is not clear whether the recall would be an improvement to PR systems in this respect. It seems more plausible to acknowledge a trade-off between increasing accountability and representing a diversity of political perspectives.

Second, if a MP is recalled, in a PR system, the substitution mechanism should be rethought. It is not clear that the seat should go to another party. If the seat left empty were automatically allocated to the leading party in the given constituency, partisans of that party would face strong incentives to recall minor parties' candidates and regain their seats, which is not the purpose of a "safety-valve." The problem would be similar, although to a lesser degree, if the recall of a MP led to an empty seat: the majority would have a tool to strengthen its power at the expense of small parties. If the benefits of proportional representation are to be preserved, one could imagine that the recalled candidate be substituted by the next person on that party's list. Citizens would thus have to wait for the next elections to sanction a party, but they would already have the ability to sanction misbehaving or undesirable individual candidates (thereby sending a message to the party).

\section{Collective Recall}

In PR systems, however, the most frequent form of recall is collective-a citizens-initiated dissolution of the whole assembly, as currently practiced in Latvia, Slovakia and in six Swiss cantons

\footnotetext{
${ }^{20}$ What can be imagined, however, in all electoral systems, is a right to recall representatives on the ground that they defend anti-democratic views. This specific form of recall would make it a contemporary functional equivalent of the ancient practice of ostracism. See Malkopoulou, 2017, Malkopoulou (2016).
} 
(Magni-Berton and Egger, 2019, pp. 81-82). This collective recall, which could theoretically be used in majoritarian systems as well, is more spectacular than the individual one and forces the organization of new elections.

Compared to the individual version, it is less harsh for political actors qua individuals and it may be less vulnerable to risks of polarization. However, it could still be instrumentalized by an opposition confident enough about its chances of winning anticipated elections.

Another weakness may be the message sent by the dissolution of a whole assembly: that all representatives are equally to blame, all corrupt-the kind of populist rhetoric that is unlikely to strengthen representative institutions in the long run.

\section{Intra-Party Recall}

Finally, intra-party recall procedures should be considered as well (see White and Ypi, 2020). They have the massive advantage of avoiding the risk of instrumentalization by the opposition. Only registered members of a given party would be allowed to sanction an elected representative who would commit misbehavior or betray key party values, for example. And the representative in question would be replaced by another party member.

Such intra-party mechanism is actually compatible with a non-partisan recall procedure. One reason to want a general recall mechanism beyond the intra-party version is that it would potentially empower more people, given the low rates of party membership in many contexts. If we are looking for ways of restoring trust in representative institutions, we might currently have to look beyond party involvement ${ }^{21}$.

\section{CONCLUSION}

The classical, elitist conception of representation on which our representative governments were built is no longer unquestioned and "the demand for additional mechanisms of accountability is widespread and unceasing" (Whitehead, 2018, p. 1354). Maybe the time has come for rethinking the representative relationship and giving citizens a sense of their democratic responsibilities and opportunities. If we still believe that it is their role, in a healthy representative democracy, to closely monitor their representatives, having a say every $4-5$ years might not be enough.

Outside academic circles and politicized groups such as the Gilets jaunes in France, many people ignore the recall. When it is known and used, however, it is unsurprisingly a very popular instrument-not in the sense that recalls are often initiated, but in the sense that citizens value this possibility (Bowler, 2004). The reason is probably that it offers what many of them consider as lacking in traditional representative institutions: more control over the representatives of the people.

This article provided a general normative assessment of this democratic tool, based both on debates in democratic theory and on the empirical research about its use around

\footnotetext{
${ }^{21}$ Which does not mean that reforms aimed at improving participation and representation inside parties are not desirable.
}

the world. From a theoretical viewpoint, I argued that the tool could be considered valuable as it expands the opportunities to monitor representatives without jeopardizing their necessary independence. Thereby, it could contribute both to reconciling citizens with electoral representation and to improving the latter by strengthening accountability and responsiveness to the majority. Nevertheless, considering the available empirical evidence, I also tried to show why our expectations should be modest. Nothing suggests that the recall would radically transform representative institutions. By the fact of sharing many traits with elections, the procedure remains affected by many of elections' shortcomings (lack of information, manipulation of voters, costly campaigns, irrelevant votes). What is more, misuses and perverse effects are frequent and teach us to be careful when designing the mechanism. We should for example consider forbidding recalls in the first part of a term in office, extending terms, having recall initiatives' justifications checked by a nonpartisan body, providing a "cooling-off period," and organizing a public hearing of both sides. As Welp and Whitehead (2020, p. 21) warn, much will depend "on the details of the rules and on broader contextual factors which are also highly variable.”

Finally, it is worth reminding that bringing representatives closer to the preferences of the majority might be desirable, but that it will not suffice to improve the quality of representation. Firstly, because democracy is not reducible to majority rule. Secondly, because the fairness of democratic decisions also heavily depends on their capacity to take account of the legitimate interests of third parties such as foreigners and future generations. The recall might therefore contribute to improving electoral representation (and not only its perceived legitimacy), but provided it is part of a larger bundle of reforms aiming at making representative institutions more inclusive, more deliberative and more reflexive.

\section{DATA AVAILABILITY STATEMENT}

The original contributions presented in the study are included in the article/supplementary material, further inquiries can be directed to the corresponding author/s.

\section{AUTHOR CONTRIBUTIONS}

The author confirms being the sole contributor of this work and has approved it for publication.

\section{FUNDING}

This research was funded by the Fonds de la recherche scientifique (FNRS, Belgium).

\section{ACKNOWLEDGMENTS}

Many thanks to Camille Bedock, François Blais, Gwénaële Calvès, Laurence Morel, Jean-Benoit Pilet, Alex Sager, Maija Setälä, Ronald Van Crombrugge and the reviewers for their very helpful suggestions. 


\section{REFERENCES}

Achen, C. H., and Bartels, L. M. (2017). Democracy for Realists: Why Elections do not Produce Responsive Government. Princeton: Princeton University Press. doi: 10.1515/97814008 88740

Altman, D. (2010). Direct Democracy Worldwide. Cambridge, MA: Cambridge University Press. doi: 10.1017/CBO9780511933950

Anderson, C. J. (2000). Economic voting and political context: a comparative perspective. Electoral Studies, 19, 151-170. doi: 10.1016/S0261-3794(99)00045-1

Bartels, L. M. (2008). Unequal Democracy: The Political Economy of the New Gilded Age. Princeton: Princeton University Press.

Bartels, L. M. (2017). "Political inequality in affluent democracies: the social welfare deficit," in Center for the Study of Democratic Institutions, Working Paper. 5-2017.

Bauer, P. C., and Fatke, M. (2014). Direct democracy and political trust: enhancing trust, initiating distrust-or both? Swiss Polit. Sci. Rev. 20, 49-69. doi: $10.1111 /$ spsr.12071

Bedock, C. (2020). Citizens' contrasting aspirations about their political system: entrustment, participation, self-identification and control. Front. Polit. Sci. doi: 10.3389/fpos.2020.563351

Bedock, C., Schnatterer, T., Bonin, L., and Liochon, P. (2019). "Au-delà de la démocratie représentative: visions du système politique et réformes institutionnelles dans le mouvement des Gilets jaunes," in Paper Presented at the Congrès de l'Association Française de Science Politique, (Bordeaux).

Benhabib, S. (2004). The Rights of Others: Aliens, Residents, and Citizens (Vol. 5). Cambridge: Cambridge University Press. doi: 10.1017/CBO97805117 90799

Blum, C., and Zuber, C. I. (2016). Liquid democracy: potentials, problems, and perspectives. J. Political Philos. 24, 162-182. doi: 10.1111/jopp.12065

Bovens, M., and Wille, A. (2017). Diploma Democracy: The Rise of Political Meritocracy. Oxford: Oxford University Press. doi: 10.1093/oso/9780198790631.003.0001

Bowler, S. (2004). Recall and representation arnold schwarzenegger meets edmund burke. Representation 40, 200-212. doi: 10.1080/00344890408523266

Brennan, J. (2016). Against Democracy. Princeton: Princeton University Press. doi: $10.1515 / 9781400882939$

Cagé, J. (2018). Le prix de la Démocratie. Paris: Fayard.

Campodonico, F. (2016). Revisiting historical justifications of the recall procedures of elected representatives. Hung. J. Legal Stud.57, 348-372. doi: $10.1556 / 2052.2016 .57 .3 .7$

Chambers, S. (2018). Human life is group life: deliberative democracy for realists. Crit. Rev. 30, 36-48. doi: 10.1080/08913811.2018.1466852

Christiano, T. (2017). Review of Jason Brennan: Against Democracy. Notre Dame Philosophical Reviews. Available online at: http://ndpr.nd.edu/news/againstdemocracy

Clarke, N., Jennings, W., Moss, J., and Stoker, G. (2018). The Good Politician: Folk Theories, Political Interaction, and the Rise of Anti-Politics. Cambridge University Press. doi: 10.1017/9781108641357

Cronin, T. E. (1989). Direct Democracy: The Politics of Referendum, Initiative and Recall. Cambridge, MA: Harvard University Press.

Dolez, C. (forthcoming). Political support in times of personalized politics: A qualitative inquiry of French citizens' representations about political actors and the political regime.

Dyck, J. J. (2009). Initiated distrust: direct democracy and trust in government. Am. Politics Res. 37, 539-568. doi: 10.1177/1532673X08330635

Egger, C., and Magni-Berton, R. (2020). "The recall in France: a long standing and unresolved debate," in The Politics of Recall Elections, eds Y. Welp and L. Whitehead (Cham: Palgrave Macmillan), 49-72. doi: 10.1007/978-3-030-37610-9_4

Estlund, D. (2008). Democratic Authority: A Philosophical Framework. Princeton: Princeton University Press. doi: 10.1515/9781400831548

Ferrin, M. (2016). How Europeans View and Evaluate Democracy. Comparative Politics. New York, Oxford University Press. doi: 10.1093/acprof:oso/9780198766902.001.0001

Forsdyke, S. (2005). Exile, Ostracism, and Democracy: The Politics of Expulsion in Ancient Greece. Princeton: Princeton University Press.
Fuchs, D., and Klingemann, H. D. (Eds.). (1995). Citizens and the State. Oxford University Press.

Garrett, E. (2004). Democracy in the wake of the california recall. Univ. Pennsyl. Law Rev. 153, 239-284. doi: 10.2307/4150625

Gerber, E. R. (1999). The Populist Paradox: Interest Group Influence and the Promise of Direct Legislation. Princeton: Princeton University Press.

Gherghina, S. (2017). Direct democracy and subjective regime legitimacy in Europe. Democratization 24, 613-631. doi: 10.1080/13510347.2016.1196355

Gilens, M., and Page, B. I. (2014). Testing theories of American politics: elites, interest groups, and average citizens. Perspect. Politics 12, 564-581. doi: $10.1017 /$ S1537592714001595

Goodin, R. E. (2007). Enfranchising all affected interests, and its alternatives. Philos. Public Affairs 35, 40-68. doi: 10.1111/j.1088-4963.2007.00098.x

Goodin, R. E., and Spiekermann, K. (2017). An Epistemic Theory of Democracy. Oxford: Oxford University Press. doi: 10.1093/oso/9780198823452.001.0001

Guinaudeau, I., and Persico, S. (2018). Tenir promesse. Revue Franç. Sci. Polit. 68, 215-237. doi: 10.3917/rfsp.682.0215

Gutmann, A., and Thompson, D. F. (1998). Democracy and Disagreement. Cambridge, MA: Harvard University Press.

Kelsen, H. (1929). The Essence and Value of Democracy. Plymouth: Rowman and Littlefield.

Landemore, H. (2013). Democratic reason: Politics, Collective Intelligence, and the Rule of the Many. Princeton University Press. doi: 10.23943/princeton/9780691155654.001.0001

Lax, J. R., and Phillips, J. H. (2012). The democratic deficit in the states. Am. J. Political Sci. 56, 148-166. doi: 10.1111/j.1540-5907.2011.00537.x

Lijphart, A. (1984). Democracies: Patterns of Majoritarian and Consensus Government in Twenty-One Countries. New Haven: Yale University Press. doi: 10.2307/j.ctt1ww3w2t

Lupia, A. (2006). How elitism undermines the study of voter competence. Crit. Rev. 18, 217-232. doi: 10.1080/08913810608443658

Madison, J. (1787). The Federalist: The Essential Essays, eds A. Hamilton, J. Madison, and J. Jay Bedford.

Magni-Berton, R., and Egger, C. (2019). RIC: le Référendum D’initiative Citoyenne Expliqué à tous. Au Cour de la Démocratie Directe. Limoges: FYP éditions.

Malkopoulou, A. (2016). De-presentation rights as a response to extremism. Crit. Rev. Intern. Soc. Polit. Philosophy 19, 301-319. doi: 10.1080/13698230.2016.1144856

Malkopoulou, A. (2017). Ostracism and democratic self-defense in Athens. Constellations 24, 623-636. doi: 10.1111/1467-8675.12285

Manin, B. (1995). Principes du gouvernement représentatif. Calmann-Lévy 2012.

Mansbridge, J. (2019). “Recursive representation," in Creating Political Presence: The New Politics of Democratic Representation, eds D. Castiglione and J. Pollack (Chicago, IL: University of Chicago Press), 298-338.

Marx, K. (1871/1972). The civil war in France. Moscow: Progress Publishers.

Matsusaka, J. G. (2004). For the Many or the Few: The Initiative, Public Policy, and American Democracy. Chicago: University of Chicago Press. doi: 10.7208/chicago/9780226510873.001.0001

Naurin, E. (2011). Election Promises, Party Behaviour and Voter Perceptions. New York, NY: Palgrave Macmillan.

Peters, Y. (2016). Zero-sum democracy? The effects of direct democracy on representative participation. Political Stud. 64, 593-613. doi: $10.1177 / 0032321715607510$

Pitkin, H. F. (1967). The Concept of Representation (Vol. 75). Univ of California Press.

Przeworski, A. (2018). Why Bother With Elections? Cambridge, MA: Polity Press.

Przeworski, A., Stokes, S. C., and Manin, B. (eds.). (1999). Democracy, Accountability, and Representation. Cambridge University Press. doi: 10.1017/CBO9781139175104

Qvortrup, M. (2011). Hasta la vista: a comparative institutionalist analysis of the recall. Representation 47, 161-170. doi: 10.1080/00344893.2011.581067

Qvortrup, M. (2020). "The political theory of the recall. A study in the history of ideas," in The Politics of Recall Elections, eds Y. Welp and L. Whitehead (Cham: Palgrave Macmillan), 29-48. doi: 10.1007/978-3-030-37610-9_3

Rosanvallon, P. (2015). Le Bon Gouvernement. Paris: Éditions du Seuil.

Rosset, J., and Stecker, C. (2019). How well are citizens represented by their governments? Issue congruence and inequality in Europe. Eur. Polit. Sci. Rev. 11, 145-160. doi: 10.1017/S1755773919000043 
Rousseau, J. -J. (1762/2008). Du Contrat Social. Paris: Flammarion.

Schiffino, N., Jacquet, V., Cogels, M., and Reuchamps, M. (2019). Les gouvernants face aux transformations de la démocratie. Le point de vue des ministres et des présidents de partis. Gouvern. Action Publique 2, 57-80. doi: 10.3917/gap.192.0057

Shapiro, I. (2016). Politics Against Domination. Cambridge, MA: Harvard University Press. doi: 10.4159/9780674970045

Somin, I. (2013). Democracy and Political Ignorance: Why Smaller Government is Smarter. Stanford: Stanford University Press.

Thomson, R., Royed, T., Naurin, E., Artés, J., Costello, R., Ennser-Jedenastik, L., et al. (2017). The fulfillment of parties' election pledges: a comparative study on the impact of power sharing. Am. J. Polit. Sci. 61, 527-542. doi: 10.1111/ajps.12313

Tonge, J. (2019). Petitions, polling stations and paisley: the first outworking of the recall of MPs act 2015. Political Q. 90, 143-147. doi: 10.1111/1467-923X.12640

Tormey, S. (2015). The End of Representative Politics. Cambridge, MA: Polity Press.

Tridimas, G. (2016). Conflict, democracy and voter choice: a public choice analysis of the Athenian ostracism. Public Choice 169, 137-159. doi: $10.1007 / \mathrm{s} 11127-016-0379-7$

Urbinati, N. (2006). Representative Democracy: Principles and Genealogy. Chicago: University of Chicago Press. doi: 10.7208/chicago/9780226842806.001.0001

Vandamme, P. É. (2020). What's wrong with an epistocratic council?. Politics 40, 90-105. doi: 10.1177/0263395719836348

Vandamme, P. E., and Verret-Hamelin, A. (2017). A randomly selected chamber: promises and challenges. J. Public Deliberation 13:1. doi: 10.16997/jdd.271

Welp, Y. (2016). Recall referendums in Peruvian municipalities: a political weapon for bad losers or an instrument of accountability? Democratization 23, 1162-1179. doi: 10.1080/13510347.2015.1060222
Welp, Y. (2018). "Recall referendum around the world: origins, institutional designs and current debates," in The Routledge Handbook to Referendums and Direct Democracy, eds L. Morel and M. Qvortrup (Abingdon, NY: Routledge).

Welp, Y., and Whitehead, L. (eds.). (2020). "Recall: democratic advance, safety valve or risky adventure?" in The Politics of Recall Elections (Cham: Palgrave Macmillan), 9-28. doi: 10.1007/978-3-030-37 610-9_2

White, J., and Ypi, L. (2020). "Reselection and deselection in the political party" in The Politics of Recall Elections, eds Y. Welp and L. Whitehead (Cham: Palgrave Macmillan), 179-200. doi: 10.1007/978-3-030-37 610-9_10

Whitehead, L. (2018). The recall of elected officeholders the growing incidence of a venerable, but overlooked, democratic institution. Democratization 25, 1341-1357. doi: 10.1080/13510347.2018.14 55665

Whitehead, L. (2020). On reconciling recall with representation. Welp Whitehead 2020a, 229-248. doi: 10.1007/978-3-030-37610-9_12

Conflict of Interest: The author declares that the research was conducted in the absence of any commercial or financial relationships that could be construed as a potential conflict of interest.

Copyright (c) 2020 Vandamme. This is an open-access article distributed under the terms of the Creative Commons Attribution License (CC BY). The use, distribution or reproduction in other forums is permitted, provided the original author(s) and the copyright owner(s) are credited and that the original publication in this journal is cited, in accordance with accepted academic practice. No use, distribution or reproduction is permitted which does not comply with these terms. 